\title{
How to Teach Recycl ing at an Advanced Phase of Diffusion
}

\section{Gonzalo Díaz Meneses}

ABSTRACT: The author conducted an empirical study based on structural equation modeling with a convenience sample of 246 individuals with the goal of demonstrating that recycling behavior is a routine conduct and should be addressed as such in educational materials. Although the classic hierarchy of effects dominates the interpretation of recycling behavior in existing literature, another cognitive model may explain this desired conduct more accurately. Results showed that the classic learning method was a powerful route to achieve the desired conduct because of its capacity to engage the evaluation holder in a conscious reexamination of ecological conscience and beliefs about recycling which underlie the evaluations. Nevertheless, recycling has become common, so today's environmentalists could provide a limited amount of information to activate recycling behavior and then to set in motion existing favorable evaluations. In addition, results showed that psychographic characteristics related to this adoption process play a moderating role in the adoption of recycling behavior. This research leads to recommendations that may improve environmental education.

KEY WORDS: cognitive-based models, ecological conscience, recycling behavior

$\mathrm{t}$ is generally accepted that individuals with ecological conscience (Bagozzi \& Dabholkar, 1994; Dispoto, 1977; Tracy \& Oskamp, 1983) and beliefs about recycling (Austin, Hartfield, Grindle, \& Bailey, 1993; Ham, 1984; Howenstine, 1993) will be conducive to recycling behavior. This leads us researchers to conclude that one way to achieve this desired conduct would be to influence those cognitive components. Hence, it is not surprising that cognitive-based attitude models have received so much attention from educators and students. Nevertheless, many particulars of the relationships between cognitions, attitudes, and behavior remain elusive, with corresponding uncertainties in terms of comprehending learning and teaching. For that reason, the environmental literature advocates that greater effort be made in constructing behavioral models that explain the dynamics of recycling behaviors (Jackson,

Gonzalo Díaz Meneses is a PhD lecturer at the University of Las Palmas of Gran Canaria, Spain. Copyright (C) 2006 Heldref Publications 
Olsen, Granzin, \& Burns, 1993; Shrum, Lowrey, \& McCarty, 1994; Wesley, Oskamp, \& Mainieri, 1995) for effective teaching strategies to be developed. In this context, I set out to estimate the cognitive models explaining recycling behavior and to find the best way of encouraging this desired conduct.

The task of educating people in environmentally-friendly behavior is complex because there are different ways to provide the target audience with information effectively. Ideally, researchers should identify the cognitive learning process with respect to recycling for each type of individual and then establish how to communicate ecological and recycling messages to each group. Many environmental educational programs fail because they focus on what the organization wants to transmit instead of on how to adjust the environmental content to the pupils' learning process (Andreasen, 1995). Thus, it seems logical to emphasize the need for educators to gain a more detailed understanding of how psychographic characteristics influence the learning process, given that personality and individual values moderate any information assimilation. In this context, we set out to explore the moderating role of psychographic characteristics on the recycling adoption process with the aim of detailing specific teaching strategies for each kind of pupil.

\section{CognitiveModels}

A cognitive approach to the encouragement of environmental behaviors can be undertaken by either a high- or a low-effect involvement hierarchy. Environmental educators almost invariably assume that they are dealing with high-involvement behaviors over which target individuals take a great deal of care. Therefore, they envisage that people consider at length and frequently seek the advice of others before taking environmentally-friendly action. Thus, educators often focus on developing a greater amount of information, and, therefore, concentrate on identifying the relevant transmitter. This predominant paradigm also affects recycling behavior and refers to the standard learning hierarchy based on both the multi-attribute attitude model (Kok \& Siero, 1985) and the theory of reasoned action (Goldenhar \& Connell 1993; Kalafatis, Pollard, East, \& Tsogas, 1999). These programs tell audiences what environmentalists want to communicate instead of transmitting more appropriate messages that take into account each type of individual's information-processing model. The appropriateness of the classic learning model for recycling should also be questioned, considering that, in contemporary Western society, recycling has become a widely-recognized and performed habit without the profound ecological connotations it had 40 years ago (Chan \& Lau, 2000; Vining \& Ebreo, 1990; Williams, 1991).

Therefore, in addition to the classic know-feel-do paradigm, it is necessary to provide an alternative cognitive strategy of influencing behavior, based on the model with a knowdo-feel hierarchy of effect. This information-processing model is related to habitual and low-commitment behaviors (Kotler \& Roberto, 1992; Macey \& Brown 1983) and is suited to the consolidation of a routine activity without the need to change attitudes, as explained by Sheriff and Hovly's social judgment theory (1964). In contrast to the standard learning process, the low-involvement hierarchy of effect describes a person collecting a minimal amount of information before acting pro-environmentally and having an emotional response only after carrying out the desired behavior.

Social judgment theory asserts that individuals assimilate new information about recycling in accordance with their existing knowledge of environmental issues and recycling. In accor- 
dance with social judgment theory and on the basis of existing environmental literature, we can distinguish two components to be specified in both kinds of models: (a) ecological conscience, which is defined as information about ecological matters and the causes of ecological damage (Arcury, Johnson, \& Scollay, 1986; Bigné, 1997), and (b) beliefs about recycling in terms of knowledge about the how, what, and why of recycling (Bagozzi \& Dabholkar 1994; Wesley et al., 1995).

One important aspect of social judgment theory is the idea that people differ in terms of the information they will find acceptable or unacceptable. They form latitudes of acceptance and rejection around an evaluation standard. Thus, ideas that fall within a latitude will be favorably received, while those falling outside this zone will not (Solomon, 1997). Because ecological conscience and beliefs about recycling are widespread in developed societies, the evaluative components associated with these will fall within the acceptance latitude. To be more specific, in relation to these cognitive components, the evaluative components or feelings specified in the models are (a) ecological concern, which refers to feelings of uneasiness about the deterioration of nature (Grunert \& Jorn, 1995; Zimmer, Stafford, \& Royne, 1994), (b) involvement with recycling, which refers to a specific degree of interest in recycling (McGuiness, Jones, \& Cole, 1977; Oskamp et al., 1991) defined as a direct assessment of recycling conduct in one's own household, and (c) general evaluation of recycling, which is a favorable or unfavorable disposition toward recycling (Oskamp et al., 1994).

The best method of influencing the recycling-adoption process of the individual might consist of a new approach called the habit model. This low-involvement model should be developed and estimated using the above five variables, as well as the conation component, or recycling conduct. In any case, relationships that could be specified in any model should be based on associations among cognitive, evaluative, and behavioral variables that appear in recycling and environmental literature (see Table 1). Thus, we put forward our first hypothesis:

$\mathrm{H}_{1}$. The model relative to a know-do-feel hierarchy of effect represents the process of recycling-behavior adoption better than the know-feel-do model does.

\section{Psychographic Characteristics}

Psychographic characteristics are clearly moderators of the recycling-adoption process (Berger \& Corbin, 1992). They systematically affect the individual's psychological core, described by the association with a cause-and-effect relationship involving three critical factors: (a) cognitions, or the know component; (b) evaluations, or the feel component, and (c) conations, or the do component. Psychographics are important because they lead to modifications in the intensity of the causal relationship of these factors, and they generate a new structure for the resulting recycling-adoption models (Wasson, 1987; Young, 1984).

The moderating role of any variable on the cause-and-effect relationship established by other variables is evident through the correlation between the moderating variable and the effect factors. This means that one should ask about the presence of recycling-related associations between people's psychographic characteristics and the variables of beliefs, attitude, and conduct (Hornik, Cherian, Madansky, \& Narayana, 1995).

According to past research, these are known as personality traits, including authoritarianism (Shrum \& Lowrey, 1995), self-efficacy (Ellen, Wiener, \& Cobb-Walgren, 1991; Gamba \& Oskamp, 1994), frugality (Young, 1988), locus of control (Hines, Hungerford, \& Tamera, 
TABLE 1. Works That Ver ify the Associations Between Cognitive Components, Components of Eval uation, and Behavior

\begin{tabular}{|c|c|}
\hline Relationship & Research Works \\
\hline Ecological conscience $\rightarrow$ Ecological concern & $\begin{array}{l}\text { Arcury (1986); Synodinos (1990); Martín \& } \\
\text { Simintiras (1995); Ling-Yee (1997); Bigné } \\
\text { (1997); Fraj et al. (2003) }\end{array}$ \\
\hline Ecological conscience $\rightarrow$ Beliefs about recycling & McGuiness et al. (1977); Fraj et al. (2003) \\
\hline Ecological conscience $\rightarrow$ Recycling attitude & $\begin{array}{l}\text { McGuiness et al. (1977); Black et al. (1985); } \\
\text { Peatty (1990); Simmons \& Widmar (1990); } \\
\text { Oskamp et al. (1991); Alwitt \& Pitt (1996) }\end{array}$ \\
\hline $\begin{array}{l}\text { Ecological conscience } \rightarrow \text { Involvement } \\
\text { with recycling }\end{array}$ & $\begin{array}{l}\text { McGuiness et al. (1977); Black et al. (1985); } \\
\text { Peatty (1990); Simmons \& Widmar (1990); } \\
\text { Oskamp et al. (1991); Alwitt \& Pitt, (1996) }\end{array}$ \\
\hline Ecological conscience $\rightarrow$ Recycling behavior & $\begin{array}{l}\text { Dispoto (1977); Fox (1991); Maibach (1993); } \\
\text { Schlegelmilch et al. (1996); Fraj et al. (2003) }\end{array}$ \\
\hline Beliefs about recycling $\rightarrow$ Ecological co & Ransey \& Rickson (1976); Synodinos (1990) \\
\hline $\begin{array}{l}\text { Beliefs about recycling } \rightarrow \text { Recycling attitude } \\
\text { Beliefs about recycling } \rightarrow \text { Involvement }\end{array}$ & Ransey \& Rickson (1976); Synodinos (1990) \\
\hline about recycling & Ransey \& Rickson (1976); Synodinos (1990) \\
\hline Beliefs about recycling $\rightarrow$ Recycling behavior & $\begin{array}{l}\text { Hines et al. (1986); Sia et al. (1986); } \\
\text { Howenstine (1993); Bagozzi \& Dabholkar } \\
\text { (1994); Shrum et al. (1994); Hornik et al. } \\
\text { (1995) }\end{array}$ \\
\hline Ecological concern $\rightarrow$ Recycling attitude & $\begin{array}{l}\text { Vining \& Ebreo (1992); Derksen \& Gartrell } \\
\text { (1993); Oskamp et al. (1994); Hornik et al. } \\
\text { (1995); Minton \& Rose (1997) }\end{array}$ \\
\hline $\begin{array}{l}\text { Ecological concern } \rightarrow \text { Involvement } \\
\text { with recycling }\end{array}$ & $\begin{array}{l}\text { Vining \& Ebreo (1992); Derksen \& Gartrell } \\
\text { (1993); Oskamp et al. (1994); Hornik et al. } \\
\text { (1995); Minton \& Rose (1997) }\end{array}$ \\
\hline Ecological concern $\rightarrow$ Recycling behavior & $\begin{array}{l}\text { Vining \& Ebreo (1992); Derksen \& Gartrell } \\
\text { (1993); Oskamp et al. (1994); Hornik et al. } \\
\text { (1995); Minton \& Rose (1997); Boleen et al. } \\
\text { (1993) }\end{array}$ \\
\hline $\begin{array}{l}\text { Recycling attitude } \rightarrow \text { Involvement } \\
\text { with recycling }\end{array}$ & Lansana (1992); Fraj et al. (2003) \\
\hline Recycling attitude $\rightarrow$ Recycling behavior & $\begin{array}{l}\text { Lansana (1992); Humphrey et al. (1977); } \\
\text { McCarty (2000) }\end{array}$ \\
\hline $\begin{array}{l}\text { Involvement with recycling } \rightarrow \text { Recycling } \\
\text { behavior }\end{array}$ & $\begin{array}{l}\text { Vining \& Ebreo (1992); McCarty \& Shrum } \\
\text { (1994) }\end{array}$ \\
\hline
\end{tabular}

1986; Pieters, 1991; Wesley et al,. 1995), and responsibility (Anderson \& Cunningham, 1972; Simmons \& Widmar, 1990; Webster, 1975). Self-awareness may also be associated with proenvironmental conduct (Anderson \& Cunningham; Pettus \& Giles, 1987), but there is a lack of empirical evaluation in the field of recycling.

Alienation is a personality trait that's association to recycling has not been demonstrated 
(Balderjahn, 1988; Pickett, Kangun, \& Grove, 1993), although Durand and Sharma (1982) pointed out this association in conservation literature, and Crosby, Gill, and Taylor (1981) made a similar indication in environmental sociology. The values of collectivism (Grunert \& Jorn, 1995; McCarty \& Shrum, 1994; Shrum \& Lowrey, 1995) and materialism (Brechin \& Kempton, 1997; Dietz, Stern, \& Guagnamo, 1998; Kidd \& Lee, 1997) also have clear associations with recycling.

On the basis of associations of these psychographic characteristics with recycling, and considering the moderating nature of this type of variable, I proposed the following hypotheses:

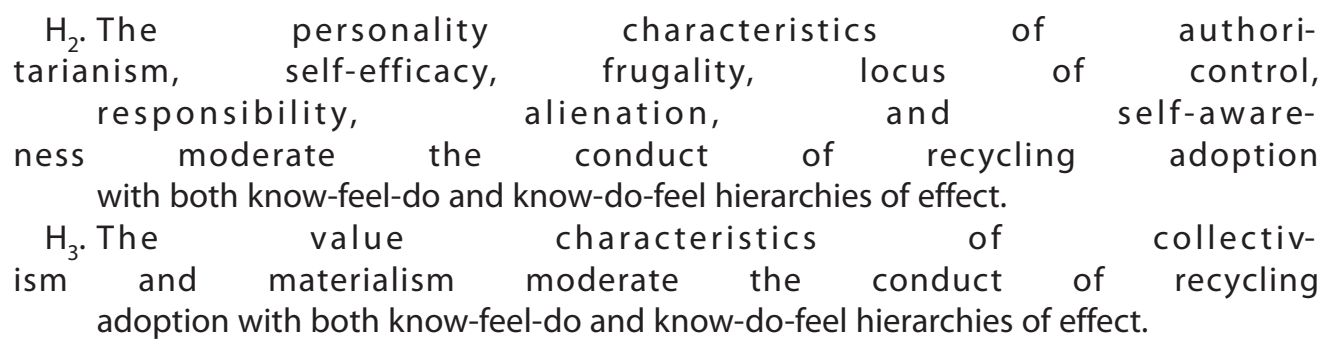

\section{Method}

I used a questionnaire to gather information about cognitive and evaluation aspects, psychographic characteristics, and recycling behavior. In the contacted households, each respondent was picked randomly among individuals who were 18 years or older. The sex distribution of the participants was 53\% women and $47 \%$ men. The average age was 45 years (range: 18-65). One member of each household was also contacted to enable direct observation of recycling behavior. In the majority of cases, those individuals were relatives of the survey target and promised not to reveal their observing function to monitor whether there was any discrepancy between actual recycling behavior and the response reported in the questionnaire. Because we were concerned that the surveyors could influence surveyed responses, we trained the surveyors thoroughly and gave them specific instructions. Surveyors were students of our teaching center who took a course on research techniques related to social sciences. They explained to those surveyed that there were neither correct nor incorrect responses. The households were selected by students from a university to people in their close social circles. Then I selected the sample following a convenience procedure and, after four entries were eliminated for various reasons, I used a final sample of 246 individuals.

I used Amos 5 for structural equation modeling in this study. I estimated with discrepancy of maximum likelihood and, to compute fit measures with incomplete data, I fit the saturated and independence models.

The scales measuring ecological conscience (Bohlen, Schlegelmilch, \& Diamantopoulos, 1993), beliefs about recycling (Scholder, 1994), and ecological concern (Biswas, Licata, McKee, Pullig, \& Daughtridge, 2000) were unipolar 5-point scales. The recycling attitude (Shrum et al., 1994) and recycling involvement scales (Zaichkowsky, 1985) were bipolar 5-point scales (see Table 2). In all cases, I measured the psychographic characteristics using unipolar, 5-point personality-trait scales, locus of control (Lumpkin \& Hunt, 1989; Rotter, 1966), self-efficacy (Roberts, 1996; Straughan \& Roberts, 1999), responsibility (Johnson \& Ostendorf, 1993), alienation (Michaels, Gron, Dubinsky, \& Joachimsthaler, 1988; Miller, 1967), self-awareness (Feningstein, Scheier, \& Buss, 1975), authoritarianism (Carlson \& Sanford, 1988), and frugality (Young, 1985, 
1988). Values scales measured collectivism (McCarty \& Shrum, 1994; Shrum \& Lowrey, 1995) and postmaterialism (Durand \& Zarrel, 1985; Lambert, 1980).

In this study, I measured the recycling of glass; paper and carton; and tetrabrick, metal, and plastic containers. I focused on these products because (a) their recycling requires the active collaboration of the public, (b) they have consolidated distribution channels in our geographical setting, the Canary Islands, Spain, which allows the public to develop the desired behavior without excessive difficulty, (c) they are environmentally important from the point of view of sustainability, and (d) the products would allow me to analyze recycling behaviors in different stages of development, because the collection systems were not implemented simultaneously, although their development is similar.

\section{Results}

Prior to testing the hypotheses, I checked the validity and reliability of the cognitive components and of the evaluation, ecological, and recycling components scales by means of

TABLE 2. Scal es Rel ated to Cognitive and Eval uative Components

\begin{tabular}{|c|c|c|}
\hline Scale & Cognitive and evaluative component & $\alpha$ \\
\hline Ecological conscience & $\begin{array}{l}\text { I know what the main ecological problems are. } \\
\text { In general, I know how not to damage the ecosystem. } \\
\text { I sufficiently understand what is said about the } \\
\text { deterioration of nature. } \\
\text { In general, I can distinguish what is bad and what is good } \\
\text { for the natural environment. }\end{array}$ & 0.8766 \\
\hline Beliefs about recycling & $\begin{array}{l}\text { I know how to recycle. } \\
\text { I know more about recycling than the average person. } \\
\text { I know what materials can be recycled. } \\
\text { I know the reasons why recycling is promoted. }\end{array}$ & 0.7692 \\
\hline Ecological concern & $\begin{array}{l}\text { When man interferes with nature, it often leads to } \\
\text { disastrous consequences. } \\
\text { Mankind is severely abusing the environment. } \\
\text { The balance of nature is very delicate and can change } \\
\text { very easily. } \\
\text { If things continue as they are, we will experience a great } \\
\text { ecological catastrophe. }\end{array}$ & 0.6733 \\
\hline Attitude toward recycling & $\begin{array}{l}\text { In general recycling behavior is Bad/Good. } \\
\text { In general recycling behavior is Stupid/Wise. } \\
\text { In general recycling behavior is undesireable/desireable. } \\
\text { In general recycling behavior is not valuable/very valuable. }\end{array}$ & 0.7692 \\
\hline Involvement with recycling & $\begin{array}{l}\text { The recycling behavior performed in my household } \\
\text { means nothing to me/lt means a lot to me. } \\
\text { The recycling behavior performed in my household is not } \\
\text { in my interest/It is in my interest. } \\
\text { I am not interested/I am interested in the recycling } \\
\text { behavior performed in my household. } \\
\text { The recycling behavior performed in my household is not } \\
\text { my responsibility/lt is my responsibility. }\end{array}$ & 0.9003 \\
\hline
\end{tabular}


exploratory factorial, Cronbach's alpha, and confirmatory factorial analyses. All scales showed acceptable values indicating reliability (see Table 2). I subjected the psychographic characteristics, which researchers consider moderating variables of the recycling-behavior model, to one exploratory factor analysis and a Cronbach's alpha test.

\section{Analysis of Mode Selection}

To develop a model that represents recycling-behavior adoption in every hierarchy of effects, I used both theoretical development and estimation. Theoretically, I considered two types of cognitive models. In line with Gerbing and Anderson (1988), the estimation phase must consist of the estimation of various alternative models to make comparisons that lead to the choice of the optimum model. To simplify the task, and because the separation or recycling systems for glass, paper or cardboard, and tetrabrick containers are implemented similarly, I standardized the recycling-behavior variable with an arithmetic average which constitutes the definitive model. Then I selected the model showing the best fit to the data in the categories of effect hierarchy by examining measures of goodness of fit.

After selecting two final models, I performed a detailed examination of the critical ratios and standardized estimators of these models. The models suggest ways in which recycling behavior might be achieved. From a cognitive-change approach and following a classic

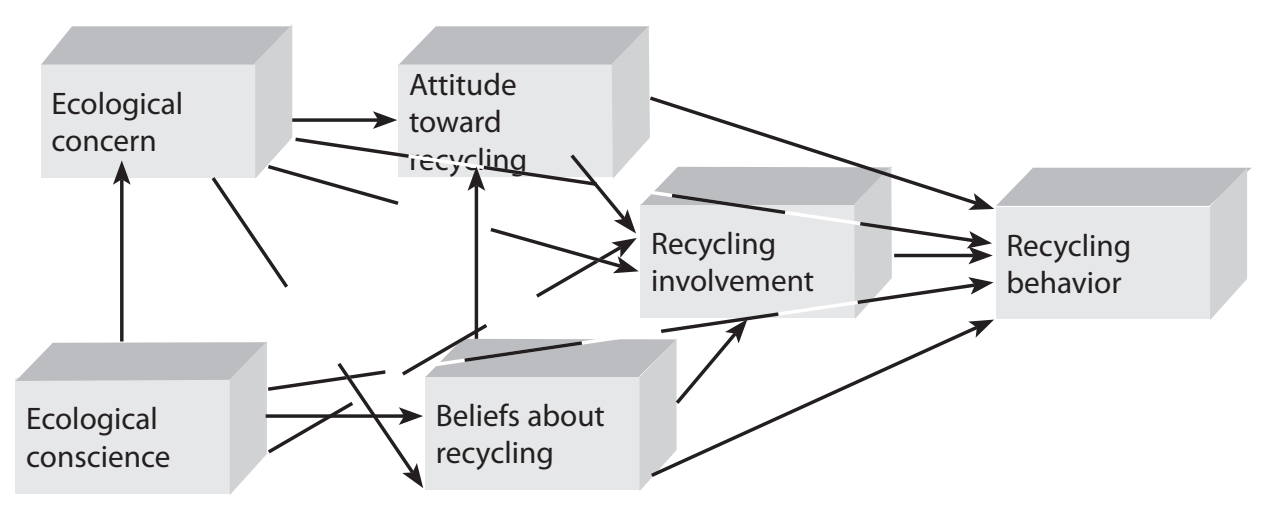

GOODNESS OF FIT INDICATORS: $\chi^{2}=0.034 ; \mathrm{df}=1 ; \mathrm{p}=.853 ; \mathrm{GFI}=1.00$, RMSEA $=0.000$; AGFI $=0.99 ; \mathrm{NFI}=1.00 ; \mathrm{RFI}=0.99 ; \mathrm{IFI}=1.00 ; \mathrm{TLI}=1.03 ; \mathrm{CFI}=1.00 ; \mathrm{CMIN} / \mathrm{DF}=0.034 ; \mathrm{RMSR}=$ $0.002 ; \mathrm{ECVI}=0.163 ; \mathrm{PNFI}=0.067 ; \mathrm{PGFI}=0.048 ; \mathrm{AIC}=40.034$. STANDARDIZED ESTIMATOR \& CRITICAL RATIOS: Ecological conscience/beliefs about recycling ( $\mathrm{SE}=0.55 ; \mathrm{CR}=9.95)$; Ecological conscience/ecological concern ( $\mathrm{SE}=0.35 ; \mathrm{CR}=5.87$ ); Ecological conscience/ involvement ( $S E=0.10 ; C R=1.59)$; Ecological conscience/behavior $(S E=0.08 ; C R=1.44)$; Beliefs about recycling/attitude toward recycling ( $S E=0.38 ; C R=6.44$ ); Beliefs about recycling/involvement ( $S E=0.22 ; C R=3.29$ ); Beliefs about recycling/behavior ( $S E=0.12 ; C R=$ 2.03); Ecological concern/beliefs about recycling ( $S E=0.03 ; C R=0.53)$; Ecological concern/ attitude toward recycling ( $\mathrm{SE}=0.07 ; \mathrm{CR}=1.20)$; Ecological concern/involvement ( $\mathrm{SE}=0.10$; $\mathrm{CR}=1.74$ ); Ecological concern/behavior ( $\mathrm{SE}=-0.06 ; \mathrm{CR}=-1.20$ ); Attitude toward recycling/ involvement $(S E=0.31 ; C R=5.41)$; Attitude toward recycling/behavior $(S E=0.44 ; C R=8.19)$; Involvement/behavior ( $\mathrm{SE}=0.22 ; \mathrm{CR}=4.03$ ).

FIGURE 1. Classic model of recycl ing behaviors. 
influencing strategy, the main lines of work to be implemented should consider two characteristics or principles: (a) ecological conscience is the only exogenous variable of this adoption model, and hence, the departure point for any strategy, and (b) beliefs about and attitude toward recycling are key variables, because they are not only direct antecedents of the desired conduct, but also indirect antecedents by virtue of involvement with recycling (see

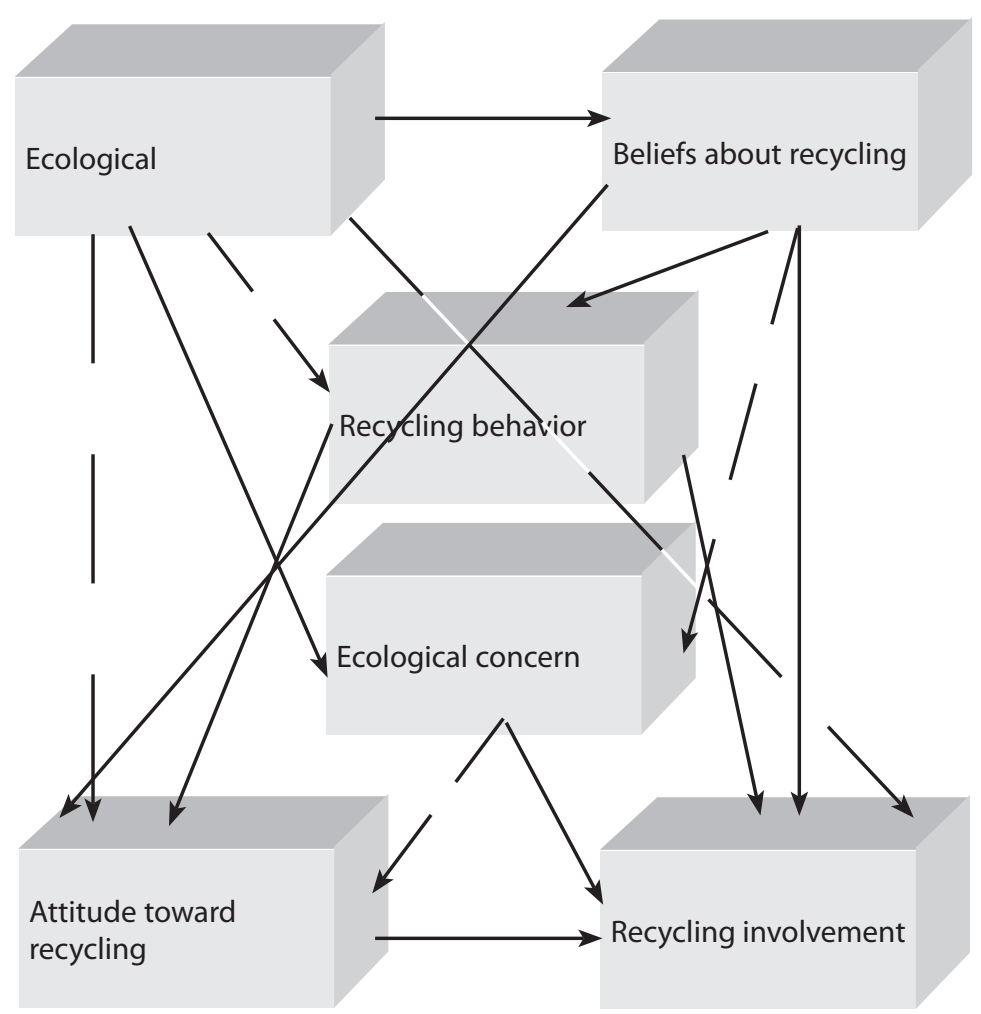

GOODNESS OF FIT INDICATORS: $\chi^{2}=0.002 ; \mathrm{df}=1 ; \mathrm{p}=.962 ; \mathrm{GFI}=1.00, \mathrm{RMSEA}=0.000 ; \mathrm{AGFI}$ $=1.00 ; \mathrm{NFI}=1.00 ; \mathrm{RFI}=1.00 ; \mathrm{IFI}=1.00 ; \mathrm{TLI}=1.03 ; \mathrm{CFI}=1.00 ; \mathrm{CMIN} / \mathrm{DF}=0.002 ; \mathrm{ECVI}=0.163$; PNFI $=0.067 ; \mathrm{PGFI}=0.048 ; \mathrm{AIC}=40.002$. STANDARDIZED ESTIMATOR \& CRITICAL RATIOS: Ecological conscience/beliefs about recycling ( $S E=0.56 ; C R=10.83$ ); Ecological conscience/ behavior ( $\mathrm{SE}=0.11 ; \mathrm{CR}=1.68$ ); Ecological conscience/ecological concern ( $\mathrm{SE}=0.32 ; \mathrm{CR}=$ 4.52); Ecological conscience/attitude toward recycling ( $S E=0.05 ; C R=-0.79$ ); Ecological conscience/involvement with recycling ( $S E=0.07 ; C R=1.17$ ); Beliefs about recycling/behavior $(\mathrm{SE}=0.37 ; \mathrm{CR}=5.37)$; Beliefs about recycling/attitude toward recycling $(\mathrm{SE}=0.17 ; \mathrm{CR}=2.78)$; Beliefs about recycling/ecological concern $(S E=0.03 ; C R=0.53)$; Behavior/attitude toward recycling $(S E=0.54 ; C R=9.75)$; Behavior/involvement with recycling $(S E=0.27 ; C R=4.03)$; Ecological concern/attitude toward recycling ( $S E=0.07 ; C R=1.32$ ); Ecological concern/ involvement with recycling ( $\mathrm{SE}=0.11 ; \mathrm{CR}=1.98)$; Attitude toward recycling/involvement with recycling $(\mathrm{SE}=0.17 ; \mathrm{CR}=2.61)$.

FIGURE 2. Habit model of recycl ing behavior. 
Figure 1). Therefore, the initial requirement is environmental education aimed at installing ecological conscience in consumers. Once this basis has been cultivated, campaigns or promotions that will increase a favorable attitude toward recycling can be created. Thus, involvement with recycling will be developed as an indirect consequence of ecological conscience, which affects both beliefs about recycling and attitude toward recycling. This sequence of cause-effect relationships among variables should be maintained to ensure that the desired recycling behavior is performed as a final result. In addition, this influencing model highlights the idea that the anxiety about the deterioration of nature is not useful, because ecological concern does not play any causal role in the model. This evidence is consistent with the theory stating that no classic learning process with a deep commitment goal can be achieved by educators transmitting negative or fear-inducing messages to audiences (Kotler, Roberto, \& Lee, 2002; Mullen \& Johnson, 1990).

A second cognitive possibility is a low-involvement influencing strategy whose guidelines can be designed on the basis of the second model (see Figure 2). In this case, the objective is to form a habit without a strong sense of commitment. As in the previous model, ecological conscience is the key initial variable because it is the only exogenous influencing factor that consolidates both beliefs about recycling and ecological concern. Thus, following the causal line described by ecological conscience and beliefs about recycling, recycling behavior might be induced by providing some information about the deterioration of nature and about factual issues related to how, when, and why to recycle. In addition, ecological conscience is the antecedent of ecological concern, which could be used to generate some involvement in recycling. Because in this model, evaluative components are seen as functions of recycling behavior, any persuasive approach must be implemented on those cognitive components so the desired conduct is adopted, and thus, attitudes toward and involvement in recycling will be modeled consistently. Therefore, the key variables are ecological conscience, beliefs about recycling, and-in contrast to the classic model-recycling behavior. In terms of the social judgment theory (Sheriff \& Hovly, 1964), (a) people would present their latitudes of acceptance around both ecological conscience and beliefs about recycling so that recycling behavior falls within their favorably appreciated latitude, and (b) people form their attitudes toward recycling in the context of what they already know.

After analyzing both models and to test the first hypothesis, I asked which of the two cognitive strategies was more suitable. To answer this question, I analyzed the goodness of fit indicators of both types of models and concluded whether each was the classic model or the low-involvement model that better represents the data. As shown in Figures 1 and 2, the goodness of fit indicators show that the habit model is more suitable. Thus, I accepted hypothesis 1 , which predicted that the model relative to a know-do-feel hierarchy of effect would represent the process of recycling-behavior adoption better than the know-feel-do model would.

\section{Expl oratory Anal ysis of Moderating Characteristics}

To explore the moderating role of psychographic characteristics in the models, I performed a multi-group analysis, taking into account the personality traits of authoritarianism, selfefficacy, frugality, locus of control, responsibility, alienation, and self-awareness, as well as the value variables of collectivism and materialism (see Table 3 ). I found significant differences in the level of responsibility, alienation, and collectivism for the classic model. Moreover, when I analyzed the differences of each regression coefficient of the relationships specified in the 
TABLE 3. Chi Squared Anal ysis of Differences by the Mul ti-GroupProcedur efor Per sonal ity and Val ues Characteristics

\begin{tabular}{|c|c|c|c|c|}
\hline \multirow[b]{2}{*}{ Characteristic } & \multicolumn{2}{|c|}{ Equality of all regression coefficients } & \multicolumn{2}{|c|}{$\begin{array}{l}\text { Equality of all regression coefficients, } \\
\text { except in significant parameters }\end{array}$} \\
\hline & $\begin{array}{l}\text { Knowledge/ } \\
\text { Affect/Behavior }\end{array}$ & $\begin{array}{c}\text { Knowledge/ } \\
\text { Behavior/Affect }\end{array}$ & $\begin{array}{l}\text { Knowledge/ } \\
\text { Affect/Behavior }\end{array}$ & $\begin{array}{c}\text { Knowledge/ } \\
\text { Behavior/Affect }\end{array}$ \\
\hline \multicolumn{5}{|c|}{ Authoritarianism } \\
\hline CMIN & 8.95 & 7.61 & - & - \\
\hline$P$ & 0.89 & 0.90 & - & - \\
\hline \multicolumn{5}{|l|}{ Self-efficacy } \\
\hline CMIN & 0.92 & 21.67 & - & 8.96 \\
\hline$P$ & 0.62 & 0.10 & - & 0.84 \\
\hline \multicolumn{5}{|l|}{ Frugality } \\
\hline CMIN & 10.52 & 11.74 & - & - \\
\hline $\mathrm{P}$ & 0.87 & 0.72 & - & - \\
\hline \multicolumn{5}{|c|}{ Locus of control } \\
\hline CMIN & 19.80 & 19.07 & 17.66 & 6.27 \\
\hline $\mathrm{P}$ & 0.15 & 0.21 & 0.22 & 0.81 \\
\hline \multicolumn{5}{|l|}{ Reponsibility } \\
\hline CMIN & 25.93 & 23.56 & 11.27 & 8.02 \\
\hline$P$ & 0.03 & 0.05 & 0.55 & 0.82 \\
\hline \multicolumn{5}{|l|}{ Alienation } \\
\hline CMIN & 26.58 & 22.18 & 7.76 & 3.80 \\
\hline$P$ & 0.02 & 0.06 & 0.80 & 0.95 \\
\hline \multicolumn{5}{|l|}{ Self-awareness } \\
\hline CMIN & 15.19 & 19.63 & 14.49 & 17.12 \\
\hline$P$ & 0.64 & 0.19 & 0.55 & 0.21 \\
\hline \multicolumn{5}{|l|}{ Collectivism } \\
\hline CMIN & 23.72 & 21.86 & 7.62 & 8.10 \\
\hline $\mathrm{P}$ & 0.05 & 0.09 & 0.88 & 0.78 \\
\hline \multicolumn{5}{|l|}{ Materialism } \\
\hline CMIN & 14.43 & 13.88 & - & 8.79 \\
\hline$P$ & 0.53 & 0.62 & - & 0.88 \\
\hline
\end{tabular}

model, I found that in the case of locus of control and self-awareness, there were statistically significant differences at a relationship parameter level in the classic model. For the habit model, I found significant differences in levels of alienation, responsibility, and collectivism. By analyzing differences of each regression coefficient of the relationships specified in the model, I found statistically significant differences for materialism at a relationship parameter level. However, authoritarianism, self-efficacy, and frugality did not show significant differences in these models.

Examination of the critical ratios and standardized estimators of the multigroup analysis afforded conclusions about the type of relationships according to the level of each characteristic. As shown in Table 4, for locus of control and alienation, neither cognitive-based model of recycling adoption showed relevant differences from a practical point of view. Although I found significant differences at some relationship parameters, they displayed the same direction of significance and, in the inverse direction, they did not pass the significance threshold. 
TABLE 4. Comparison of Critical Ratios and Standardized Estimators Froma Mul it-GroupAnal ysis Consider ing Per sonal ity Char acter istics

\begin{tabular}{|c|c|c|c|c|c|c|c|c|c|c|}
\hline \multirow{4}{*}{ Characteristic } & \multicolumn{10}{|c|}{ Equality of all regression coefficients, except in significant parameters } \\
\hline & \multicolumn{5}{|c|}{ Knowledge/Affect/Behavior } & \multicolumn{5}{|c|}{ Knowledge/Behavior/Affect } \\
\hline & \multirow{2}{*}{$\begin{array}{l}\text { Parameter of } \\
\text { relationship }\end{array}$} & \multicolumn{2}{|c|}{ Less } & \multicolumn{2}{|c|}{ More } & \multirow{2}{*}{$\begin{array}{l}\text { Parameter of } \\
\text { relationship }\end{array}$} & \multicolumn{2}{|c|}{ Less } & \multicolumn{2}{|c|}{ More } \\
\hline & & $\overline{\mathrm{SE}}$ & $\overline{C R}$ & $\overline{\mathrm{SE}}$ & $\overline{C R}$ & & $\overline{\mathrm{SE}}$ & $\overline{\mathrm{CR}}$ & $\overline{\mathrm{SE}}$ & $\mathrm{CR}$ \\
\hline \multirow[t]{2}{*}{ Locus of control } & $\mathrm{Ecs} \rightarrow \mathrm{Ecc}$ & 0.45 & 4.56 & 0.21 & 1.98 & $8 \quad \mathrm{Ecs} \rightarrow \mathrm{Ar}$ & 0.16 & 1.66 & -0.1 & -1.8 \\
\hline & $\mathrm{Ecc} \rightarrow \mathrm{Rb}$ & 0.05 & 0.67 & -0.1 & -1.4 & $\mathrm{Ecc} \rightarrow \mathrm{Ar}$ & -0.0 & -0.9 & 0.21 & 2.36 \\
\hline Responsibility & $\mathrm{Ar} \rightarrow \mathrm{Ir}$ & 0.27 & 2.63 & 0.59 & 7.45 & $5 \quad \mathrm{Ar} \rightarrow \mathrm{Ir}$ & 0.17 & 1.62 & 0.45 & 5.13 \\
\hline \multirow[t]{3}{*}{ Alienation } & $\mathrm{Ecs} \rightarrow \mathrm{Ecc}$ & 0.55 & 5.96 & 0.25 & 2.33 & $3 \quad \mathrm{Ecs} \rightarrow \mathrm{Br}$ & 0.48 & 5.02 & 0.68 & 8.45 \\
\hline & $\mathrm{Ecc} \rightarrow \mathrm{Br}$ & 0.22 & 1.93 & -0.0 & 0.75 & $5 \mathrm{Ecc} \rightarrow \mathrm{Ar}$ & 0.18 & 1.94 & -0.1 & -1.1 \\
\hline & $\mathrm{Ecc} \rightarrow \mathrm{Ar}$ & 0.14 & 1.39 & -0.1 & & & & & & 0.12 \\
\hline Self-awareness & $\mathrm{Br} \rightarrow \mathrm{Rb}$ & 0.20 & 2.21 & 0.07 & & & & & & 0.73 \\
\hline \multirow[t]{3}{*}{ Collectivism } & $\mathrm{ECs} \rightarrow \mathrm{Ir}$ & -0.1 & -0.7 & 0.26 & 2.13 & $3 \quad \mathrm{ECs} \rightarrow \mathrm{Ir}$ & -0.0 & -0.2 & 0.16 & 1.58 \\
\hline & $\mathrm{Ar} \rightarrow \mathrm{Ir}$ & 0.38 & 4.65 & 0.08 & & & & & & 1.22 \\
\hline & $\mathrm{Ar} \rightarrow \mathrm{Rb}$ & 0.37 & 4.00 & 0.67 & & & & & & 6.68 \\
\hline Materialism & $\mathrm{Ecc} \rightarrow \mathrm{Ir}$ & 0.53 & 3.01 & -0.1 & -0.6 & $\mathrm{Ecc} \rightarrow \mathrm{Ir}$ & 0.25 & 2.94 & -0.0 & -0.4 \\
\hline
\end{tabular}

Note: Ecs = Ecological conscience; $\mathrm{Br}=$ Beliefs about recycling; $\mathrm{Ecc}=$ Ecological concern; $\mathrm{Ar}=$ Attitude toward recycling; Ir = Involvement with recycling; $\mathrm{Rb}=$ Recycling behavior.

However, there was one exception; for the low-involvement process of adoption, ecological concern determined attitude toward recycling in individuals with an internal locus of control, but not in individuals with an external locus of control. This finding supports evidence that people with an internal locus of control tend to show greater ecological concern than those with an external locus of control (Huebner \& Lipsey, 1981; Leeming, Dwyer, Porter, \& Cobern, 1993; Schwepker \& Cornwell, 1991).

Similarly, in both adoption processes, attitude toward recycling influenced involvement with recycling for irresponsible individuals but not for responsible individuals. This result could mean that people who are less responsible require a favorable disposition as an antecedent to involvement in recycling, while more responsible individuals are more likely than less responsible people to follow the desired conduct of recycling, thus making the support of a favorable attitude unnecessary. This evidence indicates that educators should focus on creating a favorable attitude toward recycling in irresponsible individuals.

In a classic adoption process, beliefs about recycling are a direct antecedent of recycling behavior if an individual has less self-awareness, but beliefs are an indirect cause for both involvement with and attitude toward recycling if the individual has a greater degree of selfawareness. This result is consistent with the theory that the self-awareness response is more influenced by personal affections and cognitions relative to one's own ego (Tangney, 1999) than by external issues, such as beliefs about recycling.

The finding that involvement with recycling is a consequence of ecological conscience in more collectivist people, but is a consequence of attitude toward recycling in less collectivist people, has practical applications. This result suggests that educators trying to raise involvement with recycling should provide ecological conscience for collectivist pupils and create 
favorable attitudes toward recycling in less collectivist pupils. However, the effects of both ecological conscience and attitude toward recycling are not as clear in the low-involvement model of adoption.

Finally, given that, in both models of adoption, less materialistic people form their involvement with recycling because of ecological concern, it makes sense to emphasize this anxiety about the deterioration of nature in education programs. This strategy is consistent with environmental literature showing that people who are less attached to material possessions tend to show greater concern for ecological matters than do materialist individuals (Brechin \& Kempton, 1997; Kidd \& Lee, 1997; Lee \& Kidd, 1997). On this basis, I accept hypotheses 2 and 3 , which state that personality and values characteristics affect the conduct of recycling adoption with both know-feel-do and know-do-feel hierarchies of effect.

\section{Concl usion}

Individual differences in cognitive decisions about the recycling process illustrate how ecological conscience and beliefs about recycling can be combined to create ecological concern, attitude toward recycling, involvement with recycling, and recycling behavior. From the educational point of view, this entails a standard learning hierarchy which assumes that individuals accumulate knowledge related to ecological and recycling matters to develop highlyinvolved recycling behavior with favorable attitudes toward recycling. Although the classic approach has been prominent in past environmental literature, there is a cognitive variant approach toward achieving recycling behaviors: the low-involvement cognitive model of recycling adoption. This model recognizes the possibility that individuals simply do not care enough about recycling to assemble a set of ecological and recycling cognitions and then evaluate them. The low-involvement model implies that educators' effort to influence beliefs and carefully communicate information about recycling is generally wasted. People may not pay attention; they are more likely to respond to a minimal amount of information before starting to recycle and to have an evaluative response only after acting. In some cases, recycling might be proposed as peripheral to the individual self-concept and caused by conditioned facilities and prompt techniques.

In addition, and without denying the validity of the classic strategy, I propose that the peripheral strategy of recycling learning is most suitable if the profile of individuals' ecological learning is taken into account. The results suggest that the habit or low-involvement model may be the most efficient and effective teaching strategy, because it shows the best fit and takes into account that recycling norms are widely practiced by citizens and well-facilitated by local authorities.

Several new approaches to recycling encouragement and education can be created utilizing cognitive approaches from this research. The structure of relationships between variables in cognitive models differs according to people's psychographic characteristics, and their levels of alienation, responsibility, and collectivism for both kinds of models. In addition, locus of control and self-awareness are moderating factors of the classic model of adoption, and materialism is a moderator for the low-involvement model. It is clear that the classic learning method is a potent means of achieving the desired conduct because of its capacity to engage evaluation-holders in a conscious re-examination of their ecological conscience and beliefs about recycling. Alternatively, environmentalists might provide a limited amount of logistic information, thus activating recycling behavior without provoking any change in evalua- 
tions. However, there are not just two types of recycling adoption models; there are at least six types, depending on the target's psychographic profile. Future researchers should explore which model of recycling guidelines should be communicated to the public so educators can use the appropriate teaching tools and persuasion strategies. Educators should consider different patterns of learning and adapt recycling strategy to each target group's model of learning.

Future research should also focus on more psychographic characteristics that moderate the recycling-adoption process, including dogmatism (Anderson \& Cunningham, 1972; Heslop, Moran, \& Cousineau, 1981; Webster, 1975; Wesley et al., 1995), past orientation or conservatism (Arbuthnot, 1974, 1977), cosmopolitanism (Anderson \& Cunningham), dependence (Pettus \& Giles, 1987), and self-realization (McCarty, 2000; Shrum \& Lowrey, 1995). In this study, I used a cognitive approach to identify different methods of persuasion, but future researchers should find effective routes of persuasion as well as strategies designed to provoke the appearance of the desired conduct.

\section{References}

Anderson, W., \& Cunningham, W. (1972). The socially conscious consumer. Journal of Marketing, 36(3), $23-31$.

Andreasen, A. (1995). Marketing social change: Changing behavior to promote health, social development, and the environment. San Francisco, CA: Jossey-Bass Publishers.

Arbuthnot, J. (1974). Environmental knowledge and recycling behavior as a function of attitudes and personality characteristics. Personality and Social Psychology Bulletin, 1, 119-121.

Arbuthnot, J. (1977). The roles of attitudinal and personality variables in prediction of environmental behavior and knowledge. Environment and Behavior, 9(2), 217-232.

Arcury, T., Johnson, T., \& Scollay, S. (1986). Ecological worldview and environmental knowledge: The new environmental paradigm. Journal of Environmental Education, 17(4), 35-40.

Austin, J., Hartfield, D., Grindle, A., \& Bailey, J. (1993). Increasing recycling in office environments: The effects of specific, informative cues. Journal of Applied Behavior Analysis, 26(2), 247-253.

Bagozzi, R., \& Dabholkar, P. (1994). Consumer recycling goals and their effect on decisions to recycle: A mean end chain analysis. Psychology and Marketing, 11, 1-28.

Balderjahn, I. (1988). Personality variables and environmental attitudes as predictors of ecologically responsible consumption patterns. Journal of Business Research, 17, 51-56.

Berger, I., \& Corbin, R. (1992). Perceived consumer effectiveness and faith in others as moderators of environmentally responsible behaviors. Journal of Public Policy and Marketing, 11(2), 79-89.

Bigné, E. (1997). El consumidor verde: Bases de un modelo de comportamiento [The green consumer: ideas to develop a behavior model]. Esic-Market, 237-251.

Biswas, A., Licata, J., McKee, D., Pullig, C., \& Daughtridge, C. (2000). The recycling cycle: An empirical examination of consumer waste recycling and recycling shopping behaviors. Journal of Public Policy and Marketing, 19, 93-105.

Bohlen, G., Schlegelmilch, B., \& Diamantopoulos, A. (1993). Measuring ecological concern: A multi-construct perspective. Journal of Marketing Management, 9, 415-430.

Brechin, S., \& Kempton, W. (1997). Beyond post-materialist values: National versus individual explanations of global environmentalism. Social Science Quarterly, 78, 16.

Carlson, L., \& Sanford, G. (1988). Parental style and consumer socialization of children. Journal of Consumer Research, $15,77-94$.

Chan, R., \& Lau, L. (2000). Antecedents of green purchases: A survey in China. Journal of Consumer Marketing, 17(4), 338-357.

Crosby, A., Gill, D., \& Taylor, R. (1981). Consumer voter behavior in the passage of Michigan container law. Journal of Marketing, 45, 19-32.

Dietz, T., Stern, P., \& Guagnamo, G. (1998). Social structural and social psychological bases of environmental concern. Environment and Behavior, 30, 450-471.

Dispoto, G. (1977). Interrelationships among measures of environmental activity, emotionality and knowledge. Educational and Psychological Measurement, 37, 451-459.

Durand, R., \& Sharma, S. (1982). Conservation or energy development: Consumer perceptions of alternate solutions to the energy crisis. Journal of the Academy of Marketing Science, 10(4), 410-431.

Durand, R., \& Zarrel, L. (1985). Alienation and criticisms of advertising. Journal of Advertising, 14(3), 9-17.

Ellen, P., Wiener, J., \& Cobb-Walgren, C. (1991). The role of perceived consumer effectiveness in motivating environmentally conscious behaviors. Journal of Public Policy and Marketing, 10, 102-117.

Feningstein, A., Scheier, M., \& Buss, A. (1975). Public and private self-consciousness: Assessment and theory. 
Journal of Consulting and Clinical Psychology, 43, 522-527.

Gamba, R., \& Oskamp, S. (1994). Factors influencing community residents' participation in commingled curbside recycling programs. Environment and Behavior, 26(5), 587-612.

Gerbing, D., \& Anderson, J. (1988). An updated paradigm for scale development incorporating uni-dimensionality and its assessment. Journal of Marketing Research, 25, 186-192.

Goldenhar, L., \& Connell, C. (1993). Understanding and predicting recycling behavior: An application of the theory of reasoned action. Journal of Environmental Systems, 22(1), 91-103.

Grunert, S., \& Jorn, H. (1995). Values, environmental attitudes, and buying of organic foods. Journal of Consumer Marketing, 16, 39-62.

Ham, S. (1984). Communication and recycling in park campgrounds. Journal of Environmental Education, 15(2), 17-19.

Heslop, L., Moran, L., \& Cousineau, A. (1981). Consciousness in energy conservation behavior: An exploratory study. Journal of Consumer Research, 8, 299-305.

Hines, J., Hungerford, H., \& Tamera, A. (1986). Analysis and synthesis of research on environmental behavior: A meta-analysis. Journal of Environmental Education, 18(2), 1-8.

Hornik, J., Cherian, J., Madansky, M., \& Narayana, C. (1995). Determinants of recycling behavior: A synthesis of research results. The Journal of Socio-Economics, 24(1), 105-127.

Howenstine, E. (1993). Market segmentation for recycling. Environment and Behavior, 25(1), 86-102.

Huebner, R., \& Lipsey, M. (1981). The relationship of three measures of locus of control to environmental activism. Basic and Applied Social Psychology, 2, 45-58.

Jackson, A., Olsen, J., Granzin, K., \& Burns, A. (1993). An investigation of determinants of recycling consumer behavior. Advances in Consumer Research, 20, 481-487.

Johnson, J., \& Ostendorf, F. (1993). Classification of the five factor model with the abridged big five dimensional circumflex. Journal of Personality and Social Psychology, 65, 563-576.

Kalafatis, S., Pollard, M., East, R., \& Tsogas, M. (1999). Green marketing and Ajzen's theory of planned behavior: A cross0market examination. Journal of Consumer Marketing, 16(5), 441-460.

Kidd, Q., \& Lee, A. (1997). Post-materialist values and the environment: A critique and reappraisal. Social Science Quarterly, 78(1), 1-15.

Kok, G., \& Siero, S. (1985). Tin recycling: Awareness, comprehension, attitude, intention and behavior. Journal of Economic Psychology, 16, 157-173.

Kotler, P., Roberto, N., \& Lee, N. (2002). Social marketing: Improving the quality of life. London: Sage.

Kotler, P., \& Roberto, E. (1992). Marketing social [Social marketing]. Madrid: Diez de Santos Editorial.

Lambert, Z. (1980). Consumer alienation, general dissatisfaction and consumerism issues: Conceptual and managerial perspectives. Journal of Retailing, 56, 3-24.

Lee, A., \& Kidd, Q. (1997). More on post-materialist values and the environment. Social Science Quarterly, 78(1), $36-43$.

Leeming, F., Dwyer, W., Porter, B., \& Cobern, M. (1993). Outcome research in environmental education: A critical review. Journal of Environmental Education, 24, 8-21.

Lumpkin, J., \& Hunt, J. (1989). Mobility as an influence on retail patronage behavior of the elderly: Testing conventional wisdom. Journal of Academy of Marketing Science, 17, 1-12.

Macey, S., \& Brown, M. (1983). Residential energy conservation, the role of past experience in repetitive household behavior. Environment and Behavior, 5(2), 123-141.

McCarty, J. (2000). A structural equation analysis of the relationships of personal values, attitudes and beliefs about recycling, and the recycling of the solid waste product. Journal of Business Research, 36, 41-52.

McCarty, J., \& Shrum, J. (1994). The recycling of solid wastes: Personal values, value orientations, and attitudes about recycling as antecedents of recycling behavior. Journal of Business Research, 30, 53-62.

McGuiness, J., Jones, P., \& Cole, G. (1977). Attitudinal correlates of recycling behavior. Journal of Applied Psychology, 62, 376-384.

Michaels, R., Gron, W., Dubinsky, A., \& Joachimsthaler, E. (1988). Influence of formalization on the organizational commitment and work alienation of sales people and industrial buyers. Journal of Marketing Research, 25, 376-383.

Miller, G. (1967). Professionals in bureaucracy: Alienation among industrial scientists and engineers. American Sociological Review, 32, 755-768.

Mullen, B., \& Johnson, C. (1990). The psychology of consumer behavior. Mahwah, NJ: Lawrence Erlbaum Associates, Inc.

Oskamp, S., Harrington, M., Edwards, T., Sherwood, D., Okuda, S., \& Swanson, D. (1991). Factors influencing household recycling behavior. Environment and Behavior, 23(4), 494-519.

Oskamp, S., Williams, R., Unipan, J., Steers, N., Mainieri, T., \& Kurland, G. (1994). Psychological factors affecting paper recycling by business. Environment and Behavior, 26(4), 477-503.

Pettus, A., \& Giles, M. (1987). Personality characteristics and environmental attitudes. Population and Environment, 9(3), 127-137.

Pickett, G., Kangun, N., \& Grove, S. (1993). Is there a general conserving consumer? A public policy concern. Journal of Public Policy and Marketing, 12, 234-243. 
Copyright of Journal of Environmental Education is the property of Heldref Publications and its content may not be copied or emailed to multiple sites or posted to a listserv without the copyright holder's express written permission. However, users may print, download, or email articles for individual use. 